\title{
GRAMSCI E A EMANCIPAÇÃO DO SUBALTERNO
}

\author{
Marcos Del Roio
}

\begin{abstract}
RESUMO
Nos Cadernos do cárcere, Gramsci trabalhou com a noção de classes e grupos subalternos, conceito que vem sendo utilizado pelas Ciências Sociais e pela Historiografia atual. De forma correlata, apresentam-se os problemas do senso comum, do folclore e da religião. É importante questionar as implicações teóricas e politicas da elaboração de Gramsci, contextualizando-a no conjunto de sua produção teórico-politica, até para que se conteste o uso corrente desse conceito e sua efetiva relação com Gramsci ou quanto pode esse autor ser considerado atual para a interpretação das condições das lutas sociais no capitalismo contemporâneo.
\end{abstract}

PALAVRAS-CHAVE: Antonio Gramsci; emancipação; classes subalternas.

\section{INTRODUÇÃO}

Grande número de conceitos (re)elaborados por Gramsci em seus Cadernos do cárcere, de uma ou outra maneira, nos últimos decênios, caiu no uso comum dentro e fora da academia, ainda que com significados muito diferentes daqueles usados pelo intelectual revolucionário originário da Sardenha. Assim, não é tão simples saber do que se trata quando lemos referências sobre temas ligados a hegemonia e sociedade civil, por exemplo. Seja pelo caráter de work in progress da obra de Gramsci, seja mesmo por sua fragmentação ou ainda por sua enorme complexidade, sua obra foi disposta para muitos usos. Essa característica indica uma riqueza e uma possível permanência no tempo, mas também abre a possibilidade de ser apropriada ou decomposta por outras vertentes culturais e políticas com as quais Gramsci não poderia se reconhecer.

Certamente, a apropriação ou interpretação de maior impacto político e cultural foi feita com o conceito de sociedade civil. Um conhecido e influente texto de Norberto Bobbio, de 1967, apresentou uma leitura da noção de sociedade civil em Gramsci como se esta fosse uma parte das supra-estruturas, de modo que haveria uma diferença fundamental em relação ao uso do mesmo termo em Hegel e principalmente em Marx, para quem a sociedade civil seria identificada com a infra-estrutura. Essa interpretação, a rigor, coloca Gramsci no campo teórico do liberalismo e até por esse motivo teve grande repercussão na disputa hegemônica, contribuindo para fazer do teó- rico marxista um autor quase inócuo desse ponto de vista. De fato, Bobbio (1969) foi um autor importante na indução da chamada crise do marxismo na Itália de fins dos anos 1970 aos anos 1980.

Outra expressão de cunho gramsciano que caiu em uso nas Ciências Políticas e Sociais é indicada por classes subalternas ou grupos sociais subalternos, cujo estudo tornou-se uma tendência bastante influente na literatura científica. Desde os anos 1950, quando da primeira publicação dos Cadernos do cárcere, a Antropologia ou Ciência do Folclore, como se denominava, fez uso de Gramsci para avançar nos estudos e na interpretação da cultura popular. E. De Martino iniciou uma trajetória de estudos sobre as classes subalternas e sobre o folclore, particularmente do sul da Itália, que alimentou o debate sobre esse ponto até os anos 1970 (cf. ANGELI, 1995).

A difusão da obra de Gramsci pelo mundo anglo-americano num momento de refluxo da influência de seu pensamento na Itália e de fragmentação do movimento político e cultural de crítica da economia política do capitalismo, que o movimento operário parecia encarnar, possibilitou que seu pensamento fosse reapropriado e reordenado segundo uma perspectiva fortemente culturalista. Uma dessas posturas, vinculada aos assim chamados cultural studies, tende a observar a cultura como elemento determinante, enquanto outra - que não exclui a primeira -, de clara inspiração pós-moderna, tende a encarar a fragmentação das classes subalternas como um pressuposto metodológico e como identidade his- 
tórica marcada de positividade (cf. BUTTIGIEG, 1999).

Muitos desses estudos, na verdade, referemse à perspectiva teórica acoplada à elaboração de Foucault ou Derridà. Autores de grande importância que ampliaram o campo de estudos sobre os grupos sociais subalternos são Raymond Willians e Edward Thompson, e mais recentemente Edward Said e Stuart Hall. Importante assinalar a formação do grupo dos subaltern studies formado por intelectuais indianos como Ranajit Guha e Gayatri Spivak. Mais do que discutir a diferença entre esses autores ou avaliar a contribuição de cada um, cabe assinalar como o uso do conceito de "subalterno" se amplia enormemente. Parte-se de Gramsci como pressuposto, do camponês meridional particularmente, mas se vai adiante, com o mundo colonial e pós-colonial, o migrante, o refugiado (CURTI, 2006).

Não há dúvida de que a perspectiva universalizante de Gramsci sugere, mesmo para o capitalismo contemporâneo, uma ampliação e diversificação do conceito de subalterno, como teremos ocasião de discutir. Afinal, subalterno, do ponto de vista etimológico, significa apenas o outro inferior ou inferiorizado. Mas o que deve ser por agora destacado é que parte significativa desses estudos decorre de pressupostos teóricometodológicos que se colocam num campo bastante distante de Gramsci, que partia de pressupostos muito diferentes, quando não antagônicos a esses. Para Gramsci, a determinação essencial encontra-se nos fundamentos materiais da realidade em movimento contraditório. Dizer que a cultura ou a política está em toda parte da vida social, inclusive na economia, não é o mesmo que negar a determinação em última instância da reprodução da vida material dentro do complexo de determinações que compõe a totalidade.

A vida fragmentada das classes subalternas era vista por Gramsci como uma característica da própria situação social em que se encontram esses agrupamentos, submetidos à exploração e à opressão. Mas essa condição deve ser superada historicamente, pois à medida que essas classes deixam de ser subalternas e passam a disputar a hegemonia, ganham organicidade e a perspectiva da totalidade. É patente a diferença entre a visão conservadora que incorre o culturalismo e o pós-modernismo, limitados à defesa da identidade e dos direitos particulares, e a visão revolucionária de Gramsci.
Claro que Gramsci não poderia prever o uso que foi feito dessa categoria de classes subalternas, mas isso não resolve a questão do motivo pelo qual Gramsci passou a utilizá-la, aparentemente em detrimento das noções mais consagradas no âmbito do marxismo, como proletariado, classe operária, campesinato. Certamente que a hipótese de que seria para contornar eventuais problemas com a censura carcerária não é uma explicação razoável. Talvez seja mesmo mais tentador afiançar que se tratou de um desenvolvimento em sua elaboração, que partiu da especificidade da questão operária em direção a níveis sempre mais altos de complexidade e generalidade, sempre em busca de explicação para a materialidade da esfera subjetiva antagônica no decorrer da História. Em busca dos elementos que poderiam compor uma nova sociedade civil anticapitalista, a indeterminação e fluidez sugerida pela expressão classes ou grupos subalternos poderia ser enriquecedora.

\section{DE UM MERIDIONALISMO A OUTRO, COM A MEDIAÇÃO DA CLASSE OPERÁRIA}

A experiência dos conselhos de fábrica foi culminância de uma vivência intensa de Gramsci na "Torino operária e socialista". A luta operária por melhores condições de vida e seu esforço para desenvolver sua auto-educação e sua formação cultural à revelia da burguesia envolveram Gramsci em toda a profundidade de seu ser. A reflexão teórica que se desenrolou da experiência dos conselhos, particularmente pelas páginas do L'Ordine Nuovo, estimulou em Gramsci a concepção de uma revolução que nascia da autonomia e da auto-organização do processo fabril por iniciativa dos trabalhadores, na qual os conselhos se constituiriam nos fundamentos de uma democracia operária. A influência de Sorel é patente em Gramsci, mas também de Karl Korsch e de Rosa Luxemburg, quanto à ênfase posta na auto-organização dos trabalhadores e na centralidade da fábrica na luta política e social. Em Torino, desenrolava-se, na verdade, o último capítulo da revolução socialista internacional originada na Rússia dos czares e que se difundira pelos chamados impérios centrais (Alemanha e Áustria-Hungria) (cf. DEL ROIO, 2005, cap. 1).

A derrota da revolução socialista internacional colocou a diversidade nacional em primeiro plano, como Lênin (1976) destacara precocemente em 1920. Foi paulatinamente, mas principalmente a partir de 1923, que Gramsci passou a buscar (e 
assim até o final de sua vida) as razões da derrota do biennio rosso e os novos caminhos da revolução socialista na Itália e no mundo. Ampliando sempre seu ângulo de visão, encarando novos e sempre mais complexos problemas, Gramsci jamais deixou de conceber a centralidade do trabalho na reprodução da vida social e da fábrica na reprodução do capital, ainda que algumas leituras desse autor pretendam o contrário.

Já em 1919, Gramsci, numa perspectiva fortemente marcada pela guerra e pela revolução socialista internacional, notava que o campesinato se tornava uma força motriz da revolução socialista, fosse na Rússia ou na Itália. Percebia, então, que "quatro anos de trincheira e de exploração do sangue mudaram radicalmente a psicologia dos camponeses. Essa mudança se verificou principalmente na Rússia e é uma das condições essenciais da revolução. $\mathrm{O}$ que o industrialismo não determinou com seu normal processo de desenvolvimento foi produzido pela guerra" (GRAMSCI, 1995, p. 93).

O marxismo de Gramsci se desenvolve em paralelo a esse novo meridionalismo. Mesmo preservando a consciência da importância da questão camponesa, Gramsci se entrega à experiência dos conselhos de fábrica, defendendo ao máximo a centralidade da fábrica e do trabalho industrial na questão da transformação revolucionária, considerando ser esse o nicho principal da exploração do trabalho e da reprodução do capital. A derrota operária e as circunstâncias da fundação do PCI, em meio ao avanço do fascismo, tornaram incontornável a situação de submissão de Gramsci diante da perspectiva teórica de Bordiga.

Bordiga seguia, de alguma maneira, a tradição socialista de desprezar a questão camponesa, insistindo na exclusividade da classe operária como força da revolução. Ainda que originário de Napoli, Bordiga entendia que a revolução socialista seria obra precisamente de um partido revolucionário dotado do conhecimento científico da História, o qual deveria difundi-lo entre a classe operária a fim de que essa cumprisse sua tarefa de derrubar o capitalismo. Quanto ao campesinato, importava que se transformasse o mais rápido possível em proletariado, de modo que havia apenas a questão do capitalismo na Itália, mas não uma questão meridional como particularidade da questão agrária e camponesa.
A partir de 1923, quando Gramsci abriu luta contra Bordiga pela direção do PCI, por conta das dificuldades no enfrentamento com o fascismo e principalmente pelos problemas de grandes dimensões que os comunistas italianos encontravam em seu relacionamento com a Internacional Comunista, ocorreu enfim o encontro com a teoria política de Lênin. O meridionalismo original de Gramsci facilitou em muito a compreensão e tra$d u c ̧ a \tilde{o}$ do pensamento de Lênin para as circunstâncias concretas da Itália. Ademais, a política de frente única sugerida pela Internacional Comunista e a palavra de ordem do "governo operário-camponês" acabaram de propiciar para Gramsci uma nova leitura da questão meridional e da relação entre a classe operária e o campesinato.

Em fins de 1923, completada a ruptura com Bordiga, Gramsci já tinha a clareza da importância da questão meridional como questão nacional e da conexão que essa mantinha com a política de frente única que a Internacional Comunista procurava desenvolver desde 1921, ainda que de forma titubeante. Lamentava, então, o fato de que: "Nós não conhecemos a Itália. Pior ainda: faltamnos os elementos adequados para conhecer a Itália, assim como é realmente, de modo que nos encontramos na impossibilidade de fazer previsões, de nos orientarmos; de estabelecer linhas de ação que tenham certa probabilidade de serem exatas. Não existe uma história da classe operária italiana. Não existe uma história da classe camponesa" (GRAMSCI, 1964, p. 268-269).

Sem o conhecimento da história da particular luta de classes que forjou o capitalismo italiano, seria impossível a realização de uma frente única antifascista e anticapitalista, assim como a formulação de um projeto revolucionário centrado na classe operária e na aliança operário-camponesa. A relativa ignorância do processo histórico era agravada pelo invólucro ideológico imposto pelas classes dominantes italianas e alcançava em cheio a classe operária industrial do Norte por meio de certa concepção sociológica positivista, particularmente conservadora e discriminatória em relação ao campesinato. O próprio campesinato meridional, por sua vez, era mantido submisso por meio da religião católica e do domínio clerical.

Contudo, durante o período em que desempenhou o papel de dirigente político no movimento operário italiano (e internacional), Gramsci não 
pode mais que conhecer a classe operária italiana por sua ação política e cultural e num momento histórico muito particular de eclosão revolucionária seguida de uma queda histórica de graves proporções. O movimento dos conselhos de fábrica que se conclui com séria derrota foi seguido pela marcha triunfante do fascismo. A fase de resistência ao fascismo que se consolidava enquanto regime foi marcada pelo esforço de separar a classe operária da tradição cultural e política do socialismo italiano, enquanto este representava sua subordinação dentro do campo ideológico da burguesia e era responsável, em alguma medida, pela derrota recente.

Uma das matrizes da formação cultural de Gramsci é o meridionalismo, uma concepção político-cultural difusa e multifacetada, que teve em Gaetano Salvemini uma personalidade de ponta. Salvemini era um socialista cuja concepção destoava em muito daquela que prevalecia no PSI, exatamente por perceber no campesinato meridional um potencial voltado para a transformação social. No entanto, assim como Croce, Salvemini prestou entusiasmado apoio à participação da Itália na guerra, o que fez com que Gramsci dele se afastasse. No pós-guerra, por meio de jovens intelectuais que travam contato com o mundo operário, começa a se formar um novo meridionalismo, de caráter revolucionário, que indica no campesinato meridional uma força social propulsora de mudanças indispensáveis.

Na qualidade de deputado comunista e de principal dirigente do PCI, Gramsci encontrava-se então tomado pelo empenho de desenhar a estratégia da frente única para a Itália, que deveria encontrar na aliança operário-camponesa o núcleo gerador da revolução socialista. A fórmula política da frente única foi a chave para que Gramsci não só traduzisse Lênin para a particularidade da Itália, mas que pudesse encontrar um novo lugar pra o campesinato na estratégia revolucionária. Esse sujeito revolucionário, tão importante quanto o peso econômico e demográfico que desempenhava, foi, mais tarde - nos Cadernos do cárcere-, colocado num conjunto denominado como "classes subalternas".

No ensaio inacabado de 1926, na verdade um aprofundamento das teses do III Congresso do PCI, realizado em Lyon no início daquele mesmo ano, Gramsci aborda a questão meridional como particularidade da questão agrária na Itália, como elemento da questão nacional, seguindo o método leniniano e fazendo, portanto, sua tradução. $\mathrm{Pu}$ blicado no começo de 1930 - com o título de $\mathrm{Al}$ guns temas da questão meridional -, o texto estava de fato voltado para atrair o novo meridionalismo, cujos intelectuais observavam no campesinato do sul a força propulsora decisiva da revolução nacional e democrática, mas percebiam também a importância do operariado setentrional nesse processo (GRAMSCI, 1995).

Gramsci se colocava já o problema da unificação das classes subalternas da Itália como uma contribuição à unificação do gênero humano. A questão meridional é então, de fato, uma questão internacional. A reflexão de Gramsci, na mesma medida que particulariza/nacionaliza a questão meridional italiana, a internacionaliza. A unificação das classes subalternas da Itália, contudo, deve unificar a classe operária dentro de uma perspectiva política e cultural que reconheça a necessidade da aliança com o campesinato, num contexto internacional de atualidade da revolução socialista.

Um conjunto de fragmentos ideológicos sistematizados sob a forma de reformismo impedia a unificação da classe operária na perspectiva apregoada por Gramsci e também impedia a aliança operário-camponesa. Já a canalização da rebeldia camponesa em direção à ação política transformadora de suas condições sociais só poderia ocorrer em caso de fratura na burocracia estatal e no bloco intelectual que dava sustentação àquela ordem social. Daí se segue a necessária crítica aos grandes intelectuais meridionais que elaboram a hegemonia burguesa na Itália, com Croce em primeiro lugar.

Na verdade, o debate travado entre Gramsci e a revista Quarto Stato era não só uma luta pela conformação da frente única e da aliança operário-camponesa, como uma disputa pela hegemonia no interior da coalizão das forças revolucionárias, situação na qual os intelectuais e a cultura desempenhariam um papel essencial. É patente a analogia dessa disputa entre aliados com a disputa ocorrida no processo revolucionário russo entre os marxistas bolcheviques e os neonarodiniks.

Esse problema ganhava um destaque ainda maior na reflexão de Gramsci porquanto eram os intelectuais tradicionais, o meridionalismo conservador, a preservar o bloco agrário, e com ele o domínio dos industriais e banqueiros do Norte. 
Assim que, graças à mediação de um bloco intelectual conservador "o Mezzogiorno pode ser definido como uma grande desagregação social; os camponeses, que constituem a grande maioria da sua população, não têm nenhuma coesão entre si" (idem, p. 174).

A possibilidade de uma revolução camponesa, dada a incapacidade dessa camada de gerar intelectuais orgânicos, estava em forjar uma aliança com a classe operária por meio dos intelectuais meridionalistas liberal-revolucionários da estirpe de Gobbetti ou Dorso, aos quais - junto com os comunistas - caberia cindir o bloco intelectual meridional e lutar contra o capitalismo, aliando o campesinato à classe operária.

\section{DAALIANÇAOPERÁRIO-CAMPONESAÀS CLASSES SUBALTERNAS}

Gramsci, um meridionalista de novo tipo, que do Mezzogiorno só conhecia a Sardenha natal, extraordinariamente passou a ter ciência da enorme diversidade cultural da Itália meridional apenas no cárcere, de seu caráter de rebeldia prépolítica, de como era real a "desagregação social", mas de como muitas mediações estavam presentes. Em carta enviada ainda em 1926, da prisão de Ústica, Gramsci dizia a Tânia da possibilidade de "fazer observações de psicologia e de folklore de caráter único". Dizia que "quatro divisões fundamentais existem: os setentrionais, os centrais, os meridionais (com a Sicília), os sardos". Notava que os sardos viviam apartados dos outros grupos, que os setentrionais não se organizavam, os romanos se organizavam bem, e que "os meridionais são organizadíssimos, ao quanto se diz, mas entre eles há subdivisões: o Estado napolitano, o Estado pugliese, o Estado siciliano" (GRAMSCI, 1996, p. 19).

Agora Gramsci já começa a notar importantes mediações na "desagregação social" dos subalternos, particularmente do Mezzogiorno. Havia diferenças culturais e valorativas que distinguiam as diversas regiões de origem dos segregados, o que seria um impeditivo para se colocar toda a Itália meridional dentro de um mesmo enquadramento. As observações de Gramsci continuavam e classificava até mesmo os prisioneiros políticos: "Os mais calmos serenos e comedidos são os camponeses, depois vêm os operários, depois os artesãos, por fim os intelectuais, entre os quais ocorrem explosões imprevisíveis de loucura absurda e infantil" (idem, p. 32).
Mais tarde, aprofundando suas observações, Gramsci escrevia que eram quatro os Estados da marginalidade meridional, acrescentando o Estado calabrês aos três antes enunciados. Mas, dessa vez, quase como uma nova descoberta, narrava que "os sicilianos são um caso a parte; há mais semelhanças entre um calabrês e um piemontês do que entre um calabrês e um siciliano" (idem, p. 70).

O início da vida de prisioneiro foi uma experiência que provocou em Gramsci o renovado interesse por temas que ocupavam sua mente de estudante universitário em Torino, temas ligados à antropologia lingüística, ao folclore, à cultura italiana. As observações "etnográficas" que teve ocasião de fazer no cárcere ofereceram também um material empírico bastante rico para pensar a complexidade dos grupos subalternos da Itália. Podemos dizer então que essa pesquisa de campo forçada - em que se misturavam prisioneiros políticos de diversas origens com marginais também de origens bastante diferentes - sugeriu a Gramsci que as classes subalternas eram um universo muito amplo e complexo. Dar-se conta dessa realidade era imprescindível a fim de se realizar uma política revolucionária capaz de unificar esses grupos e elevá-los culturalmente a um nível superior de consciência crítica.

Essas observações que Gramsci identificava como sendo atividade "bizantina" certamente contribuíram para a formulação do projeto de pesquisa que pretendia desenvolver no cárcere. Assim, seu primeiro plano de estudo visava "uma pesquisa sobre os intelectuais italianos", "uma lingüística comparada", "a transformação do gosto teatral italiano", "os romances de apêndice e o gosto popular na literatura". O fio condutor de todo o empreendimento estaria na busca dos graus e fases de desenvolvimento do "espírito popular criativo" (idem, p. 56).

Qual a relação existente entre esse início de vida carcerária, com os sofrimentos e as observações e reflexões que ensejou, e particularmente o plano de estudo elaborado com o escrito sobre a questão meridional, redigido apenas quatro meses antes? Entre um texto de crítica política e polêmica ideológica como esse e o temário de perfil quase acadêmico agora apresentado no plano de estudo? Na verdade, há sim uma relação de continuidade. No escrito sobre a questão meridional, o objetivo político imediato se fazia evidente na de- 
fesa da necessidade dos intelectuais críticos, fossem marxistas ou liberal-revolucionários, de proceder à fratura no bloco intelectual meridional conservador e assim possibilitar a organização do campesinato e sua aliança com a classe operária.

Agora o plano é de maior amplitude e profundidade, mas é ainda o mesmo. Trata-se de conhecer a Itália, de conhecer a cultura popular, mais precisamente o folclore ou o senso comum das classes subalternas (embora essa expressão ainda não compareça). Mais ainda, de saber como esse senso comum se articula com a concepção dos intelectuais e como podem ser ambas transformadas.

O "espírito popular criativo" que conduz e unifica a pesquisa poderia ser a busca de elementos de criação e de rebeldia popular diante das formas diversas de dominação? Seria o folclore uma forma de as classes subalternas interpretarem a visão sistematizada dos grupos sociais dominantes e de seus intelectuais e de transformarem a opressão e a submissão em condição suportável? Ou poderiam também mimetizar formas de recusa e rebeldia? Não estaria Gramsci em busca de elementos de rebeldia espontânea presente na vida social das massas, particularmente do campesinato, que tocaria aos intelectuais revolucionários canalizar como vontade coletiva? Apesar das muitas modificações no plano de estudo na vida de prisioneiro, não parece que Gramsci tenha fugido muito dessa impostação original, dessas perguntas. Nos Cadernos do cárcere, porém, Gramsci não mais usou a expressão "espírito popular criativo", possivelmente para se precaver de cair em alguma armadilha de marca idealista ${ }^{1}$.

Por outro lado, sempre nos Cadernos do cárcere, Gramsci passou a utilizar a expressão "classes subalternas" e "grupos subalternos", numa possível ampliação do mesmo campo analítico. Há alguma implicação teórico-metodológica nessa mudança? Há alguma implicação política?

Já no primeiro caderno e no caderno 2, algumas notas de Gramsci sugeriam a ampliação da noção de meridione para todo o mediterrâneo, dentro da dialética nacional/internacional, da subalternidade imposta pelo colonialismo. O ca-

${ }^{1}$ Essa passagem em particular, mas o conjunto do texto se deve ao estimulante diálogo com Giorgio Baratta, cujo ponto de partida pode ser visto em Baratta (2003, p. 32-35). derno 3, redigido em 1930 e considerado de miscelânea, começa com anotações principalmente sobre intelectuais e o americanismo, temas cruciais da pesquisa de Gramsci. Quase que improvisamente aparece uma curta nota, a de número 14, nomeada História da classe dominante e história das classes subalternas, que traz uma observação essencial de caráter metodológico. Nessa nota extraordinariamente sintética, destacam-se, desde logo, duas observações decisivas para se elucidar o raciocínio de Gramsci: 1) "a história das classes subalternas é necessariamente desagregada e episódica"; 2) "há na atividade dessas classes uma tendência à unificação, ainda que em planos provisórios, mas essa é a parte menos visível e que se demonstra somente com a obtenção da vitória" (GRAMSCI, 1977, Q 3, § 14 , p. $299-300)^{2}$.

A primeira afirmação tem um caráter bastante geral e indica a situação histórica das classes subalternas, que "sofrem a iniciativa da classe dominante, mesmo quando se rebelam; estão em estado de defesa alarmada". A segunda observação, cujas implicações não são desenvolvidas nessa passagem, sugere que as classes subalternas, por "iniciativa autônoma", tendem à unificação e, nessa condição, à superação da subalternidade, à hegemonia. As classes subalternas unificadas em torno de uma perspectiva autônoma propõem uma nova hegemonia, uma nova ordem social (ibidem).

Essas observações trazem à tona, mais uma vez, a continuidade e o diálogo permanente de Gramsci com seus interlocutores quase que presumidos, mas que estiveram presentes em sua concepção teórico-política, desenvolvida na ação dos dias em que viveram os conselhos de fábrica de Torino. As referências explícitas a Sorel e a Rosa Luxemburg nunca foram numerosas em Gramsci, nem no período revolucionário de 19171921, nem nos Cadernos do cárcere, o que não significa que preocupações comuns e incidências no pensamento não estivessem presentes.

Como se sabe, Sorel foi importante expoente teórico do sindicalismo revolucionário e Rosa Luxemburg uma notável personalidade da Neue Linke do SPD - Partido Social-Democrata da Ale-

\footnotetext{
2 A partir de agora, os Quaderni del carcere, de Antonio Gramsci (1977), serão referidos pela letra Q seguida do número do caderno, o parágrafo e a página.
} 
manha - e fundadora, depois, do KPD - Partido Comunista da Alemanha. Guardadas as muitas diferenças entre esses autores, em Gramsci incidia a comum preocupação com a auto-atividade das massas, a auto-organização e o autogoverno. Em suma, com um "espírito de cisão" presente na atividade das classes submetidas. O problema passa a ser o endereço que toma a "iniciativa autônoma" das massas e como a "tendência à unificação" deve ou pode ocorrer.

Gramsci não indica o como e o porquê dessa tendência, mas uma possível suposição encontrase na proposição marxiana da dinâmica do capital como agente da unificação da classe operária, mas essa suposição se mostra falsa se considerarmos a presença de alguma forma de economicismo em Marx. Por outro lado, é falsa também essa suposição, por certo, se considerarmos grupos sociais subalternos de formações sociais pré-capitalistas.

Gramsci parte desse substrato comum, dessa preocupação comum, com Sorel e Rosa, da iniciativa espontânea das massas, do que poderíamos chamar "espírito de cisão" ou "espírito popular criativo". Em Sorel, critica a permanência na subalternidade cultural ao liberalismo por manter a divisão entre o econômico e o político. A concepção teórica da organização dos trabalhadores estritamente no campo econômico, educados em torno do mito da greve geral contra o capital e o Estado político, era insuficiente para criar uma situação nova de hegemonia, exatamente por negar a política e a atividade intelectual revolucionária. O mesmo economicismo presente em Sorel, Gramsci critica também em Rosa Luxemburg, pelo menos em seu trabalho sobre a revolução russa de 1905. Segundo o argumento de Gramsci, também em Rosa haveria uma tendência economicista ao sugerir que crises econômicas pudessem ser geradoras espontâneas de situações revolucionárias (Q 13, § 24, p. 1613).

Os indícios são todos de que, para Gramsci, qualquer forma de economicismo representa uma variante de subalternidade teórica. Mas essa afirmação tem um significado ainda mais incisivo: a emancipação do subalterno supõe que a unificação passe também pela emancipação cultural, pela percepção de que o econômico e o político (e o filosófico) são expressões de uma mesma realidade em movimento: a emancipação do subalterno passa pela construção de um novo bloco histórico e, como constitutivo desse processo, de uma reforma moral e intelectual (uma revolução cultural gerada na auto-educação das massas). Eis a razão da grande importância do estudo do folclore, da religiosidade, do senso comum, das formas de organização das classes subalternas. É o socrático "conhece-te a ti mesmo" como condição da transformação.

\section{CLASSES SUBALTERNAS E INTELEC- TUAIS}

Passagens dissociadas de diferentes cadernos podem fazer pensar que a expressão "classes subalternas" leva a um grau de abstração e generalidade tal a torná-la estéril do ponto de vista analítico ou mesmo político ${ }^{3}$. Por que então Gramsci a utiliza, além de ir ainda mais longe com o uso do termo "grupos subalternos"? A resposta possível pode apontar em duas direções diferentes e complementares. A primeira é a possibilidade de se estender o campo analítico no tempo e no espaço. O indício claro disso está em parágrafos subseqüentes do caderno 3, nos quais Gramsci trata das classes subalternas das comune italianas da época medieval (§ 16) e da antiga Roma (§ 18). Com essas questões em mente, podem ser vasculhadas as diversas camadas culturais que compõem o folclore e o senso comum da Itália, particularmente do campesinato.

Nessa lógica, pode (deve) ser estudada a origem e a formação da classe operária, como particularidade essencial do mundo moderno. Essa categoria de classes ou grupos subalternos permite ainda que o campo analítico se amplie para zonas coloniais, como já foi sugerido, exatamente como Gramsci entendia ser a condição da própria Itália meridional ou até mesmo a América Latina, como sugere o parágrafo 5 desse mesmo caderno 3. Ou seja, a generalidade do termo "classes subalternas" ou "grupos subalternos" possibilita a análise apurada de particularidades as mais diversas dentro de uma tendência geral à unificação do gênero humano.

Mas essa ampliação do campo de visão analítica não traria também como implicação a indefinição prática e política? Aqui a resposta não pode passar do terreno das hipóteses, a menos que se proceda a uma pesquisa muito mais acurada. A importância que Gramsci dava ao americanismo

3 O mesmo pode ser dito da categoria de "revolução passiva”, que está fora dos objetivos do presente escrito. 
e ao fordismo como tema de pesquisa comprova como a centralidade do trabalho fabril persistia em sua crítica da modernidade capitalista, o que aponta na direção oposta a uma possível diluição da classe operária no seio de indefinidos e pulverizados "grupos subalternos". Mantida a centralidade operária na construção de uma nova hegemonia antípoda ao domínio do capital, as classes subalternas da época capitalista ganham uma coluna vertebral por meio da qual podem ganhar organicidade e proceder na tendência à unificação e à hegemonia.

O problema passaria, então, a ser aquele de distinguir social e culturalmente quais seriam, entre os grupos subalternos, os possíveis aliados da classe operária. Seria apenas o campesinato? $\mathrm{Ou}$ o campesinato seria tão diverso em sua formação cultural, em seu folclore, que nem analítica e nem politicamente poderia ser visto como uma entidade exatamente homogênea, até mesmo por ser uma classe de transição, uma classe do pré-capitalismo que deveria ser colaboradora da transição socialista, conforme havia demonstrado a elaboração do último Lênin? Mais amplamente, seria ainda de se questionar o quanto haveria de particularidades nos diferentes estratos camponeses herdados da época feudal na Europa ou se o chamado campesinato das vastas zonas coloniais não teriam também sua enorme diversidade?

A teoria da história que Gramsci desenvolveu nos Cadernos do cárcere nada tinha de esquemática ou linear, assim como sua concepção de classe social. A noção de subalterno pode parecer demasiadamente elástica, mas é fato que a questão meridional italiana já ganhava uma nova complexidade, assim como a própria noção de questão meridional já se ampliava para a zona colonial do imperialismo. A questão da unificação das classes subalternas italianas é uma questão nacional, mas, ao mesmo o tempo, é uma questão de unificação das classes subalternas de todo o mundo, uma questão de unificação do gênero humano.

Essa interpretação só é possível, porém, com a leitura de outras muitas passagens dos Cadernos do cárcere, particularmente do caderno 13, no qual Gramsci analisa formas e modos pelos quais as classes subalternas podem superar sua condição. Na verdade, no caderno 13, no qual retoma anotações feitas em cadernos anteriores, Gramsci trata particularmente da situação da classe operária, de um ponto de vista metodológico, de seu formar-se como classe capaz de dirigir um arco de alianças composto pelo conjunto das classes subalternas contra a dominação burguesa. Permanece, portanto, no fundo, o problema da aliança operário-camponesa e da frente única, esboçada no período imediatamente precedente ao encarceramento, notadamente em Alguns temas da questão meridional.

Gramsci se questiona sobre como se forma uma vontade coletiva, ou seja, sobre o como se unificam as classes subalternas. Ou, dito de outra maneira, como a cultura das classes subalternas se rompe e se transforma em cultura e vontade coletiva antagônica à das classes dominantes, rompendo-se assim a subalternidade. Esse problema é crucial não só no conjunto dos Cadernos do cárcere, mas em toda a elaboração da cultura política do marxismo.

Um movimento de emancipação só pode partir da auto-atividade das massas, de sua autonomia, da cisão com a classe dominante. Gramsci interpreta $O$ Príncipe, de Maquiavel, com as lentes de Sorel, exatamente para destacar esse personagem imaginário como a representação da vontade coletiva autônoma que se auto-organiza em oposição à ordem social vigente, gerando uma cisão que contesta a subalternidade. Esta demanda, todavia, uma reforma moral e intelectual, uma transformação cultural de grande envergadura histórica, que supere e substitua a cultura da velha classe dominante.

Entretanto, essas lentes não são suficientes para enxergar que não basta a negação radical da ordem. É preciso também, e ao mesmo tempo, que se materialize a nova subjetividade, o que significa organizar a vida material e cultural sobre novas bases. A negação da velha ordem significa também elaboração teórico-prática de um projeto de nova vida. Não um projeto em abstrato, mas construído segundo a condução possível do movimento do real e que parte "do acordo alcançado nas vontades associadas” (Q 13, § 1, p. 1537).

A nova subjetividade, crítica e negativa da condição subalterna, parte necessariamente das condições reais existentes, das contradições do real, dos fragmentos que compõem a ideologia subalterna, dos impulsos de rebeldia dos dominados (quase a dizer, do "espírito popular criativo"). A recomposição dos fragmentos culturais e ideológicos emerso da rebeldia dos dominados, na perspectiva de negação da subalternidade, demanda 
necessariamente uma reforma moral e intelectual de largo alcance, no sentido da recomposição de toda a vida material e cultural.

Esse movimento histórico só se torna possível desde que as classes subalternas gerem um grupo de intelectuais orgânicos. Orgânicos porque emersos do seio da própria classe e porque atuam historicamente em razão dos interesses da classe da qual se originaram. Organizados, constituem o Príncipe moderno, um organismo que é "um elemento de sociedade complexo no qual já tenha início a concretização de uma vontade coletiva reconhecida e afirmada parcialmente na ação" (Q 13, § 1, p. 1558).

Se for assim, fica evidente que não se pode pensar a condição subalterna e a luta por sua emancipação dissociada dos grupos intelectuais. Então, em Gramsci, a história do folclore, da religiosidade, do senso comum das classes subalternas enfim, não pode estar dissociada das formas de domínio que lhe são impostas com decisiva contribuição dos grupos intelectuais. Assim também a negação/superação da condição subalterna não pode passar ao largo da formação de um grupo intelectual autônomo forjado pelas próprias classes subalternas em luta contra sua condição. Aqui se percebe como o caderno 12, que trata da história dos intelectuais, e o caderno 27 , que fala da história das classes subalternas, fazem parte de uma mesma pesquisa.

De fato, no caderno 12, Gramsci se refere implicitamente aos intelectuais orgânicos da burguesia e aos necessários ao proletariado: "Cada grupo social, nascendo no terreno originário de uma função essencial no mundo da produção econômica, se cria juntamente, organicamente, uma ou mais camadas de intelectuais que lhe dão homogeneidade e consciência da própria função não só no campo econômico, mas também no social e político". Depois é que amplia a questão para os intelectuais originados da época feudal e arremata: "A categoria dos eclesiásticos pode ser considerada a categoria intelectual organicamente ligada à aristocracia fundiária" (Q 12, §1, p. 15131514).

A explicação das razões pelas quais na Itália do século XVI não se formou uma vontade coletiva que unificasse a península sob forma de monarquia absoluta, Gramsci encontra nas características cosmopolitas dos intelectuais, cuja origem remonta ao Império Romano, mas que a Igreja de
Roma preservou e desenvolveu. O Renascimento foi um empreendimento cultural de elevada qualidade e valor, mas foi uma iniciativa de frações da nobreza que colocaram os artistas e intelectuais sob sua égide, não permitindo que se transformasse em fenômeno de massa, que atingisse as camadas sociais subalternas.

A Reforma religiosa, pelo contrário, significou uma reforma moral e intelectual de longo alcance, não só pela tendencial laicização da vida terrena, com a valorização do trabalho e da acumulação da riqueza, mas pela negação do universalismo da Igreja de Roma. O contato imediato do fiel com seu deus, mediado pelo pastor, rompeu a hierarquia católica e regionalizou a organização religiosa, contribuindo assim na formação de Estados territoriais. Em determinadas regiões (como na Alemanha), a reforma reforçou o poder local da nobreza, mas em outros contribuiu na gestação da revolução burguesa (como na Holanda, na Inglaterra e nos Estados Unidos). De todo modo, esteve muito longe de alcançar um padrão cultural que se aproximasse ao menos do Renascimento.

Isso significa que a Reforma desenvolveu um papel contraditório, mas contribuiu também para que eclodisse o jacobinismo na Revolução Francesa. Jacobinismo aqui entendido como um grupo intelectual que expressa a vontade coletiva nacional-popular. Pensando assim, Gramsci podia ver em Maquiavel um precursor do jacobinismo, como alguém que percebe no universalismo da Igreja de Roma o inimigo a ser batido a fim de que prevalecesse uma vontade coletiva representada na figura do Príncipe, maneira pela qual as classes subalternas se fariam protagonistas da formação de um Estado territorial pelo qual se difundisse o Renascimento como fenômeno de massa. A difusão do Renascimento como fenômeno de massa poderia ser a geradora de uma civilização de homens universais, como Gramsci percebia em Leonardo da Vinci.

Sorel notava os intelectuais e políticos das classes dominantes como partícipes de um mesmo bloco histórico, mas precavia a classe dos produtores da geração de intelectuais ou dirigentes que poderiam vir a ser beneficiários de outras formas de dominação. Daí seu antijacobinismo, sua postura de cisão da vida política e intelectual dos dominantes, sua negação da forma partido político. Gramsci, que na juventude teve uma visão bas- 
tante aparentada a essa, nos Cadernos passa a ver o jacobinismo precisamente como a ação de um grupo dirigente gerado e organicamente vinculado às classes subalternas, ainda que em graus e medidas diferentes.

Em seu diálogo com Sorel (mediado por Maquiavel), Gramsci concebe o partido revolucionário como um intelectual orgânico coletivo, formado como instrumento concreto capaz de canalizar a rebeldia dos subalternos, de recompor os fragmentos ideológicos de recusa da ordem, de promover uma reforma moral e intelectual que negue a subalternidade, concebendo um novo projeto de vida social. A rebeldia espontânea das classes subalternas é conduzida para um projeto de hegemonia, não deixada entregue ao espontaneísmo, como em Sorel.

Continuando a interlocução com Sorel, sempre no caderno 13, Gramsci discute como as diversas formas de sindicalismo e corporativismo preservam a condição subalterna da classe operária, exatamente por não colocar no horizonte o problema da hegemonia, imprescindível para a fundação de uma nova ordem, de um novo Estado. O limite teórico do sindicalismo corporativo, mesmo na vertente revolucionária soreliana é o economicismo, antes de tudo porque reproduz a visão da vida social que é própria do liberalismo, da ideologia da classe dominante.

Ao identificar todo o político como instância de dominação da classe no poder, o sindicalismo revolucionário reconhece como real a falsa dicotomia entre o econômico e o político, entre a sociedade civil e o Estado. De modo que o sindicalismo é uma variante do economicismo, é ideologia de uma classe que continua a ser subalterna. O sindicalismo teórico "enquanto se refere a um grupo subalterno, ao qual com essa teoria se impede de vir a ser alguma vez dominante, de desenvolver-se para além da fase econômicocorporativa para elevar-se à fase de hegemonia ético-política na sociedade civil e dominante no Estado" (Q 13, § 18, p. 1590).

Na teoria e na ação política, "a luta pode e deve ser conduzida desenvolvendo o conceito de hegemonia [...]" (Q 13, § 18, p. 1595-1596), condição para que a classe operária possa se emancipar da situação de subalternidade. O que pode significar essa afirmação? Que a condição subalterna só pode vir a ser superada desde que a classe operária assuma a perspectiva da totalidade.

Assumir a perspectiva da totalidade comporta dois significados plausíveis, que se completam. $\mathrm{O}$ primeiro seria que a classe operária assume a perspectiva do interesse do conjunto das classes subalternas no processo de negação da subalternidade, ou seja, no processo de emancipação da exploração e da opressão, implicando um programa, um projeto, um momento de construção. O segundo seria que deveria se dotar de uma perspectiva cultural e teórica adequada, que metodologicamente parta do princípio que "economia" e "política", sociedade civil e Estado são uma mesma e única realidade, que pode ser abordada por diferentes pontos de aproximação; essa perspectiva da totalidade não poderia ser outra que a oferecida pela filosofia da práxis.

Decerto que as classes subalternas não são apenas a classe operária e o campesinato, mesmo quando o argumento gira em torno da crítica ao capitalismo, ainda que dependa muito do grau e da fase de desenvolvimento em que se encontra determinada nação ou povo. Artesãos também são sobrevivências da ordem feudal ou outras, assim como são estratos de comerciantes ou de intelectuais tradicionais. Todos esses grupos sociais são subalternos e tendem sofrer a hegemonia burguesa, "a iniciativa da classe dominante". Não é diferente com a classe operária, com o proletariado industrial, a não ser por um ponto decisivo: a classe operária produz a mais-valia do qual o capital se alimenta, e é capaz, ainda que com enormes dificuldades, de produzir também intelectuais orgânicos e cultura crítica. Por outro lado, "a massa dos camponeses, ainda que desempenhe uma função essencial no mundo da produção, não elabora intelectuais 'orgânicos' próprios e não assimila nenhuma camada de intelectuais 'tradicionais' [...]" (Q 12, § 1, p. 1514).

Caberia então à classe operária, uma classe subalterna particular, agrupar o conjunto das classes subalternas para a luta contra o capitalismo e por uma nova ordem social. Para isso, era imprescindível conhecer/transformar suas culturas particulares e fragmentárias que se expressavam como folclore, como religião, como senso comum, e, por meio de um "progresso intelectual de massas", gerar uma nova cultura, invólucro de uma nova hegemonia e de um novo bloco histórico. Para isso tudo, a formação de uma camada de intelectuais orgânicos seria imprescindível. 
O que Gramsci faz é, ao fim das contas, aprofundar e desenvolver a fórmula política da frente única e da aliança operário-camponesa, com as quais trabalhava no momento da prisão. Somente uma coalizão do conjunto das classes subalternas, orientadas pela classe operária e seus intelectuais orgânicos - o Príncipe moderno -, poderia se constituir em força antagônica e alternativa ao capitalismo.

Assim, o conjunto das classes subalternas, negando sua condição por meio de uma reforma moral e intelectual, com sua associação de vontades, transformar-se-ia em uma nova sociedade civil (e em um novo Estado), materializando uma nova hegemonia. Quando fala de nova sociedade civil e de novo Estado, Gramsci supõe o Estado operário, o Estado socialista. Esse Estado é obra do conjunto dos grupos sociais que se emanciparam da subalternidade e alcançaram o estatuto de construtores de uma nova civilização.

\section{GRAMSCI EM FÓRMIA}

Um indício forte dessa leitura encontra-se precisamente no desenvolvimento do trabalho de Gramsci depois de ser transferido do cárcere de Turi para a clínica de Fórmia. Retoma, então, no caderno 22, o projeto de reflexão crítica sobre o americanismo e fordismo, que parecia ter sido deixado para trás, voltando a insistir e mostrar a importância crucial da classe operária no mundo moderno.

Se, nos cadernos 25 e 27, Gramsci trata da história e da cultura dos grupos subalternos que sobrevivem, no caderno 22, debruça-se sobre o novíssimo produzido pelo capitalismo: o americanismo fordista. $\mathrm{O}$ americanismo fordista é, para Gramsci, um intento de anular a lei tendencial da queda do lucro capitalista, quando então "as classes subalternas, que teriam que ser 'manipuladas' e racionalizadas de acordo com as novas metas, necessariamente resistem" (Q 22, § 1, p. 2139). Aqui, a iniciativa da classe dominante é de tal ordem que "a racionalização determinou a necessidade de elaborar um novo tipo humano, adequado ao novo tipo de trabalho e de processo produtivo" (Q 22, § 2, p. 2146).

A classe operária fordista ainda está sendo elaborada pela iniciativa hegemônica da burguesia, de modo que ainda não se mostrou capaz de criar supra-estruturas de classe que a levassem a colocar em pauta a questão da hegemonia. Na verda- de, nas condições de implantação do fordismo, "a hegemonia nasce da fábrica e necessita apenas, para ser exercida, de uma quantidade mínima de intermediários profissionais da política e da ideologia” (Q 22, § 2, p. 2146).

Ora, a novíssima classe operária ainda está em construção, não é e ainda está longe de ser uma classe em condições de colocar em questão a hegemonia em disputa. Pelo momento, é ainda um grupo subalterno, uma classe subalterna que não consegue se unificar e muito menos ser o núcleo de um arco de alianças no qual se veja a frente única das classes subalternas. Por um lado, é muito mais avançada do que a classe operária russa que fez a revolução socialista ou a classe operária italiana que pôs em prática a tão marcante experiência dos conselhos de fábrica, mas, por outro, é uma força política e cultural apenas potencial e muito embrionária. A racionalização capitalista da produção sob a forma taylorista e fordista, como avanço do maquinismo e do automatismo, gera uma situação contraditória de aprofundamento da alienação e de criação das condições para a negação da subalternidade operária. Cria a condição para que o indivíduo trabalhador se aproprie parcialmente da técnica produtiva, mas o isola e fragmenta do ser classe operária.

No caderno 25, Gramsci recolhe, com poucas mudanças, as anotações anteriormente feitas e atribui o nome, nesse caderno especial, de Nas margens da história. História dos grupos sociais subalternos. O convite ao trabalho é de uma imensidão significativa e Gramsci oferece apenas alguns poucos indícios, mas a orientação da pesquisa está clara e definida. De certa forma, é um contraponto com o temário do caderno 22.

Nesse caderno 25, o parágrafo 14 do caderno 3 é transcrito com modificações. Antes de tudo, o título assume seu caráter de Critérios metodológicos. Percebe-se que a expressão "classes subalternas" é substituída por "grupos subalternos", mas não desaparece do texto. Agora, Gramsci explicita que a tendência à unificação desses grupos é continuamente destroçada pela iniciativa dos grupos dominantes, de modo que essa tendência pode ser demonstrada apenas em caso de sucesso. Gramsci também explicita melhor a passagem do caderno 3: "Os grupos subalternos sofrem sempre a iniciativa dos grupos dominantes, mesmo quando se rebelam e se insurgem: só a vitória 'permanente' rompe, e não ime- 
diatamente, a subordinação. Na realidade, mesmo quando parecem triunfantes, os grupos subalternos estão só em estado de defesa alarmada" (Q $25, \S 2$, p. 2283-2284).

Essa passagem é mais explícita e, ao mesmo tempo, mais ampla e profunda. A expressão "grupos subalternos" refere-se também a camadas sociais que não podem ser definidas como classe propriamente dita, como o caso de grupos intelectuais ou mesmo de classes que não se formaram ainda como tal. Por outro lado, Gramsci acentua a dificuldade em se romper a subalternidade e o risco da ilusão de vitória. Parece que, aqui, Gramsci repercute as dificuldades e os problemas que se desdobravam na União Soviética ${ }^{4}$.

Gramsci aprofunda suas observações metodológicas no parágrafo 5 , no qual mostra cabalmente a impossibilidade de se fazer uma história (e de se fazer política) das classes subalternas dissociada da totalidade social, que se expressa a partir do Estado das classes dirigentes. Diz Gramsci a propósito: "A unidade histórica das classes dirigentes ocorre no Estado e a sua história é essencialmente a história dos Estados e dos grupos de Estados". De modo que "a unidade histórica fundamental, pela sua concretude, é o resultado das relações orgânicas entre Estado ou sociedade política e 'sociedade civil'. As classes subalternas, por definição, não são unificadas e não podem unificar-se até que não possam vir a ser 'Estado': a sua história, portanto, é entrelaçada com a da sociedade civil, é uma função 'desagregada' e descontínua da história da sociedade civil e, por esse trâmite, da história dos Estados e dos grupos de Estados" (Q 25, § 5, p. 2288).

As classes subalternas podem compor um novo Estado, uma nova totalidade, precisamente a partir do momento em que negam a subalternidade e se emancipam. Conhecer e transformar são aspectos e momentos da filosofia da práxis, da ciência da história e da política. Por isso, Gramsci enuncia alguns pontos essenciais de pesquisa para quem se arrisca a fazer história das classes subal-

\footnotetext{
4 É sempre bom lembrar que uma citação isolada muito pouco pode garantir, mas se observarmos outras linhas dos Cadernos nas quais Gramsci sugere estar a União Soviética em estágio "econômico-corporativo", percebemos como entende a subalternidade não ter sido efetivamente vencida naqueles países.
}

ternas tendo em mente o projeto de sua emancipação. Historiador aqui não é apenas o especialista nos estudos dos acontecimentos do passado, mas é o intelectual orgânico que faz a história junto com as classes subalternas, no sentido de práxis. É preciso conhecer a origem e o desenvolvimento dos grupos sociais subalternos, seu grau de adesão à ordem existente, sua capacidade de impor reivindicações próprias, o surgimento de formações dos grupos dirigentes voltados a manter a subalternidade, o surgimento de formações dos grupos subalternos que afirmem seus interesses dentro da ordem ou que lutem contra a subalternidade.

Ao fim das contas, Gramsci insiste no problema posto em 1923, sobre a necessidade de se conhecer a Itália a fim de transformá-la. Apenas que agora seu ângulo de visão é muito mais amplo e universal. Continua também acompanhado da interlocução com Sorel. Para Gramsci, em síntese: "o historiador deve notar e justificar a linha de desenvolvimento em direção à autonomia integral, desde as fases mais primitivas, deve notar cada manifestação de soreliano 'espírito de cisão"'. São imensas, porém, as dificuldades para o historiador que projeta a história, não só por conta da fragmentação dos grupos subalternos, mas também em razão das "repercussões das atividades bem mais eficazes, pois que surgidas do Estado, dos grupos dominantes sobre aqueles subalternos e sobre os seus partidos" (Q 25, § 5, p. 22882289).

Gramsci começa o caderno 25 exatamente com a sugestão de um trabalho monográfico de pesquisa. Aborda o fenômeno histórico-social de Davide Lazzaretti (1834-1878), um líder rebelde emerso das camadas subalternas da Toscana. Profeta místico, Lazzaretti era também um pregador em oposição à monarquia, tal como se apresentava a Igreja. Gramsci critica a bibliografia existente sobre o evento, identificando a tendência a se isolar o fato, a fim de que fosse atribuída uma natureza patológica ao personagem central da trama, já que, "para uma elite social, os elementos dos grupos subalternos têm sempre alguma coisa de barbaresco e de patológico" (Q 25, § 1, p. 2279).

Assim, a literatura existente, na verdade, contemplando os interesses das classes dominantes, procurava "esconder as causas do mal-estar geral que existia na Itália depois de 1970, dando a 
cada um dos episódios de explosão de tal mal-estar, explicações restritivas, individuais, folclorísticas, patológicas etc. A mesma coisa ocorreu em maior dimensão para o 'brigantaggio' meridional e das ilhas" (Q 25, § 1, p. 2280).

O interesse de Gramsci nesse episódio particular encontra-se precisamente na manifestação de "popularidade e espontaneidade", assim como "qual tendência subversiva-popular-elementar podia nascer entre os camponeses em seguida ao abstencionismo político clerical e ao fato de que as massas rurais, na ausência de partidos regulares, se procuravam dirigentes locais que emergiam da própria massa, misturando a religião e o fanatismo ao conjunto de reivindicações que de forma elementar fermentavam nos campos" (Q $25, \S 1$, p. 2280 bis).

Nas páginas desse caderno, Gramsci tece considerações sobre aspectos da história dos grupos subalternos na Roma antiga e na época feudal e destaca que "no Estado antigo e naquele medieval, a centralização, seja político-territorial, seja social, (e um não é mais que função do outro) era mínima”. Nessa situação, "os grupos subalternos tinham uma vida própria, em si, instituições próprias etc., e às vezes essas instituições tinham funções estatais, que faziam do Estado uma federação de grupos sociais com funções diversas não subordinadas [...]". Em contraposição, "o Estado moderno substitui o bloco mecânico dos grupos sociais pela subordinação à hegemonia ativa do grupo dirigente e dominante, de modo que abole algumas autonomias, que porém renascem de outra forma, como partidos, sindicatos, associações de cultura". Referindo-se ao fascismo, Gramsci anota ainda que "as ditaduras contemporâneas abolem legalmente também essas novas formas de autonomia e se esforçam para incorporá-las na vida estatal: a centralização legal de toda a vida nacional nas mãos do grupo dominante se faz 'totalitário"” (Q 25, § 4, p. 2287).

Gramsci avalia então como os grupos subalternos da Antiguidade Clássica e da época medieval se acoplavam ao grupo dominante, mas tinham uma vida própria, normas e padrões culturais próprios. Em caso de sanada a dificuldade documental, a história desses grupos não seria difícil de ser elaborada. Na época burguesa, o Estado tende a centralizar a atividade da classe dominante, tende a coordenar a hegemonia sobre a classe operária e o conjunto dos grupos subalternos. Estes, por sua vez, manifestam sua autonomia por meio de organizações econômicas, políticas e culturais. O empenho do Estado e da classe dominante é submeter essa autonomia e bloquear o eventual desenvolvimento do "espírito de cisão", caminho para a negação da subalternidade, constituindo a hegemonia.

Nessa mesma linha de reflexão segue o caderno 27, composto apenas por algumas poucas páginas tratando de Observações sobre o "folclore". Gramsci observa como a literatura existente, sendo sempre uma expressão da "ciência" das classes dominantes, concebe a Ciência do folclore apenas como uma coleção de informações pitorescas que podem se manifestar como conhecimento erudito. Para Gramsci, no entanto, o folclore deveria ser estudado, tal como entendem certas correntes da Antropologia, como cultura, mais especificamente como cultura popular. Diz então Gramsci sobre o folclore: "Ocorreria estudálo em vez como 'concepção do mundo e da vida', implícita em grande medida, de determinados estratos (determinados no tempo e no espaço) da sociedade, em contraposição (também essa no mais implícita, mecânica, objetiva) com as concepções do mundo 'oficiais' (ou em sentido mais amplo das partes cultas da sociedade historicamente determinadas) que se sucederam no desenvolvimento histórico. (Assim a estreita relação entre folclore e "senso comum" que é o folclore filosófico). Concepção de mundo não só não elaborada e sistemática, porque o povo (ou seja, o conjunto das classes subalternas e instrumentais de cada forma de sociedade que até agora existiu) por definição não pode ter concepções elaboradas, sistemáticas e politicamente organizadas e centralizadas no seu contraditório desenvolvimento, mas que pelo contrário são múltiplas - não só no sentido de diverso, e justaposto, mas também no sentido de estratificado do mais grosseiro ao menos grosseiro - se até mesmo não se deve falar de um aglomerado indigesto de fragmentos de todas as concepções de mundo e da vida que se sucederam na história, das quais a maior parte, ou seja, só no folclore se encontram as sobrevivências documentais mudadas e contaminadas" (Q 27, § 1, p. 2311-2312)

Essa longa e pouco clara passagem exige bem um comentário. A rigor, para Gramsci, o folclore é composto pela concepção de mundo e de vida das classes subalternas. Mas essa concepção de 
mundo e de vida também se contrapõe à visão de mundo e de vida dos grupos dirigentes e, mais especificamente, de seus intelectuais. Essa contraposição, em geral, ocorre sob forma de releitura fragmentada da cultura dos grupos dirigentes em sucessão histórica. Ainda mais, a concepção de mundo e de vida das classes subalternas é múltipla, estratificada, justaposta e misturada, já que essas camadas sociais, por sua própria condição, não podem contar com uma visão de mundo e da vida sistemática e elaborada como Filosofia.

O "senso comum" é o sedimento superior do folclore, porquanto é folclorização da Filosofia das classes dirigentes. Assim, a Filosofia e a Ciência modernas oferecem sempre novos elementos que se transformam em senso comum, em folclore. Parece que aquilo que Gramsci chama de "lorianismo" seja precisamente uma forma de folclore da ciência. De modo que "o folclore pode ser entendido só como um reflexo das condições de vida cultural do povo, se bem que certas condições próprias do folclore se prolonguem mesmo depois que as condições sejam (ou pareçam) modificadas ou dêem lugar a combinações bizarras" (Q 27, § 1, p. 2312).

A religião é outro elemento conectado com o folclore (e com o senso comum), particularmente por configurar uma moral. Note-se que, no catolicismo, e também na vertente ortodoxa do cristianismo, há uma diferença significativa entre a religião popular (dos simples) e a religião dos intelectuais. Nesse campo da moral religiosa, também devem ser discernidos os diversos estratos culturais: "aqueles fossilizados que espelham condições de vida passada e, portanto, conservadores e reacionários, e aqueles que são uma série de inovações, muitas vezes criativas e progressivas, determinadas espontaneamente de formas e condições de vida em processo de desenvolvimento e que estão em contradição, ou somente diferentes, da moral dos estratos dirigentes" (Q 27, § 1, p. 2313).

Veja-se como, na reflexão de Gramsci, aparecem elementos que enriquecem e diversificam o conceito e o entendimento de folclore. Longe de ser um universo fixo e estéril, o folclore é apresentado como um universo de representações ideológicas no qual a religião, a moral, a ciência e a filosofia se estratificam e se misturam, ganhando formas diversas e móveis de dominação e de imposição da subalternidade. Mas Gramsci não deixa de notar a presença do "espírito popular criativo" no folclore, criações culturais espontâneas que podem ser elementos de negação da subalternidade. No folclore, aparecem espontaneamente momentos de autonomia e de antagonismo dos grupos sociais subalternos.

Da mesma maneira, Gramsci também sugere que, frente à filosofia da práxis, toda a religião e toda a filosofia das classes dirigentes e de seus intelectuais podem ser encaradas como folclore, como camadas culturais de um tempo que deverá ser passado. Na verdade, a própria filosofia da práxis pode encontrar aspectos de folclore em seu processo de desenvolvimento e de difusão. Somente com o aprofundamento dessa perspectiva crítica é que se poderá induzir "o nascimento de uma nova cultura nas grandes massas populares, ou seja, desaparecerá o destaque entre cultura moderna e cultura popular ou folclore. Uma atividade desse gênero, feita em profundidade, corresponderia no plano intelectual a isso que foi a Reforma nos países protestantes" (Q 27, § 1, p. 2314).

\section{CONSIDERAÇÕES FINAIS}

Algumas conclusões muito provisórias podem ser avançadas ao fim deste breve escrito. Pode-se dizer, antes de tudo, que há uma continuidade significativa de preocupações no conjunto da obra de Gramsci. Desde muito jovem, Gramsci esteve voltado, em sua ação política e cultural, para o problema da emancipação, para a questão da liberdade. Partindo de uma consciência relativamente difusa da situação de opressão em que vivia a Sardenha, Gramsci concebe uma análise que observa toda a região meridional da Itália como uma zona colonial, que faz do campesinato uma camada social particularmente submetida. No entanto, foi a vivência com a classe operária de Torino que informou Gramsci da contradição e da exploração capitalista, amadurecendo, então, nele, a convicção da necessidade do desenvolvimento do "espírito de cisão" como condição fundamental da emancipação do trabalho.

Assim, de suas ações e reflexões sobre os conselhos de fábrica, em 1919-1920, até o estudo sobre o americanismo-fordismo contido no caderno 22, de 1934, Gramsci esteve mergulhado na questão da emancipação da classe operária. $\mathrm{Na}$ verdade, mesmo antes, quando escrevia artigos 
jornaleiros de crítica cultural, literária e artística, a reflexão de Gramsci guardava esse objetivo e desde logo fê-lo compreender que a emancipação não poderia jamais se limitar a uma mudança pura e simples das condições materiais ou jurídicas e que mesmo essas exigiriam uma capacidade de auto-organização, de auto-educação e de autonomia das massas exercitando e desenvolvendo o "espírito popular criativo".

Pode-se dizer que, mesmo antes da fundação do Partido Comunista, em 1921, no cabedal cultural e teórico de Gramsci, já se encontravam presentes os elementos que lhe possibilitaram o desenvolvimento teórico realizado em seguida e culminado nos Cadernos do cárcere. Em sua fase de dirigente do PCI, Gramsci perseguiu o objetivo de emancipar a classe operária da ideologia reformista positivista que garantia a subalternidade operária e também contribuía fortemente para preservar a condição de opressão na qual os camponeses se encontravam reduzidos. De início (ainda junto a Bordiga), preocupou-se com a unificação da classe operária, mas depois seu campo de visão se ampliou e se focou na questão da aliança operário-camponesa, no problema da unificação das classes exploradas e oprimidas sob o capitalismo. Era o momento da ruptura com Bordiga e da tradução de Lênin para a particularidade italiana no contexto do capitalismo.

Gramsci era já ciente de como os intelectuais socialistas eram subalternos às classes dirigentes e como serviam de intermediários para manutenção da classe operária na situação de impotência. Refletia com acuidade sempre maior no papel dos intelectuais na manutenção da situação de atraso do Mezzogiorno. Sem que a classe operária formasse seus próprios intelectuais e sem que se desorganizasse o bloco intelectual meridional, a emancipação dos trabalhadores não seria possível. Às vésperas da prisão, Gramsci havia já concebido uma estratégia para a revolução antifascista e anticapitalista, sintetizada na fórmula política da frente única e da aliança operário-camponesa.

No cárcere, Gramsci aprofundou e ampliou notavelmente essa linha de reflexão e pesquisa. Percebeu a enorme diversidade do mundo camponês, sua riqueza cultural, as manifestações do "espírito popular criativo", sempre em busca de virtualidades antagônicas do campesinato e da cultura popular que pudessem enriquecer a aliança com a classe operária, tal como Gramsci de- fendia. Da mesma forma, Gramsci ampliou seu raio de visão, perscrutando, a partir da questão meridional italiana, uma questão meridional planetária, composta por imensa e diversificada zona colonial. Eis a importância cultural e política do estudo da lingüística, do folclore e de outros temas que se propôs a estudar na vida de prisioneiro do fascismo.

Gramsci notou também que a própria classe operária era uma composição histórica e social diferenciada. Não era a mesma na Rússia, na Alemanha, na Itália ou nos Estados Unidos. Por evidente que possa parecer essa assertiva, nela está implícita uma questão de método muito importante, com implicações políticas bastante sérias. Avaliar a origem social e histórica, a experiência pregressa de luta e a cultura popular é importante no processo de constituição da classe operária, de sua capacidade de se elevar culturalmente e propor uma nova hegemonia, superando a subalternidade.

Parece que Gramsci percebera, no cárcere, que a classe operária da Europa, com toda a sua diversidade, fora derrotada em 1921 e que a "época de revolução passiva" que então se iniciara, entre outras coisas, tendia a remodelar o perfil da classe operária, como "iniciativa dos grupos dominantes". Era o caso exemplar do americanismofordismo com seu potencial universalizante no contexto do capitalismo. A classe operária havia sofrido uma grave derrota histórica e começava a ser recomposta sob o padrão fordista-taylorista de produção capitalista e a própria União Soviética se encontrava em um estágio "econômicocorporativo", ou seja, num estágio muito primário da transição socialista.

Não seria então o caso de ampliar e aprofundar o campo de visão analítica tanto da classe operária, do campesinato, da intelectualidade, todos esses grupos sociais em mutação e vivendo tempos históricos diferentes, passando a se utilizar um conceito mais amplo, mais abrangente, como o de classes subalternas ou de grupos sociais subalternos? O problema teórico-prático continuava a ser o mesmo, apenas que ciente do grau imenso de complexidade: como se forjar uma frente única das classes subalternas tendo em vista sua emancipação da exploração e opressão do capital, partindo de sua diversidade e fluidez e da produção de sempre novas formas de folclore, que ficou conhecida como cultura de massas. Catego- 
rias fixas e imutáveis pouco ou nada contribuiriam para a construção do devir histórico.

Certo que o método de Gramsci, seu historicismo radical, ofereceu condições não só para que sua obra fosse mal-entendida ou mesmo manipulada, assim como categorias que foram de seu uso encontraram outros usos que em nada coincidiam com os objetivos do autor sardo. Mas, por outro lado, a fluidez dos grupos subalternos percebidas por Gramsci no momento que escrevia tem semelhanças significativas com o mundo de hoje, quando muito se fala da crise do movi- mento operário, da sociedade do trabalho, do fordismo, quando é colocada em discussão a própria existência de uma classe operária. A fluidez da luta social, a existência de movimentos de grupos subalternos os mais variados, localizados ou globalizados, permitem que Gramsci viva no século XXI e nos coloque o desafio de descortinar o novíssimo, que poderá (ou não) conduzir a formação da frente única das classes subalternas do capitalismo mundializado como Império. Mas condição para que isso ocorra é que a própria filosofia da práxis não seja dada por alguma espécie de folclore (MONAL, 2003).

Marcos Del Roio (delroio@terra.com.br) é Doutor em Ciência Política pela Universidade de São Paulo (USP) e Professor de Ciência Política da Universidade Estadual Paulista Júlio de Mesquita Filho (Unesp).

\section{REFERÊNCIAS BIBLIOGRÁFICAS}

ANGELI, P. 1995. Gramsci, De Martino e la crise della scienza del folclore. In : BARATTA, G. \& CATONE, A. (orgs.). Antonio Gramsci e il "progresso intellettuale di massa". Milano : Unicopli.

BARATTA, G. 2003. Le rose e i Quaderni : il pensiero dialógico di Antonio Gramsci. Roma : Carocci.

BOBBIO, N. 1969. Gramsci e la concezione della società civile. In : ROSSI, P. (org.). Gramsci e la cultura contemporânea. V. 1. Roma : Riuniti.

BUTTGIEG, J. A. 1999. I "subalterni” nel pensiero di Gramsci. In : BURGIO, A. \& SANTUCCI, A. A. (orgs.). Gramsci e la rivoluzione in Occidente. Roma : Riuniti.

CURTI, L. 2006. Percorsi di subalternità : Gramsci, Said, Spivak. In : CHAMBERS, I. (org.). Esercizi di potere: Gramsci, Said e il postcoloniale. Roma : Maltemi.
DEL ROIO, M. 2005. Os prismas de Gramsci : a fórmula política da frente única (1919-1926). São Paulo : Xamã.

GRAMSCI, A. 1964. Per la verità : scritti (19131926). Roma : Riuniti. no : Einaudi.

1977. Quaderni del carcere. $2^{\mathrm{a}}$ ed. Tori.1995. Disgregazione sociale e rivoluzione : scritti sul Mezzogiorno. Napoli : Liguori. Sellerio.

1996. Lettere del carcere. Palermo :

LENIN, V. I. 1976. La enfermedad infantil del "izquierdismo" nel comunismo. In :__. Obras escogidas en doce tomos. T. XI. Moscú : Progreso.

MONAL, I. 2003. Gramsci, a sociedade civil e os grupos subalternos. In : COUTINHO, C. N. \& TEIXEIRA, A. P. (orgs.). Ler Gramsci, entender a realidade. Rio de Janeiro : Civilização Brasileira. 


\section{GRAMSCI AND THE EMANCIPATION OF THE SUBALTERN}

\section{Marcos Del Roio}

In his Prison Notebooks, Gramsci worked with the notion of subaltern classes and groups, a concept that has been incorporated by the Social Sciences and current Historiography. Correlatedly, problems of common sense, folklore and religion are presented. It is important to raise the question of the theoretical and political implications of Gramsci's elaborations, contextualizing them within the entirety of his theoretical and political production, even if only to contest the common uses of the concept and their real relationship to Gramsci, or to examine to what extent this author can be considered relevant for interpretations of the conditions of social struggle in contemporary capitalism. KEYWORDS: Antonio Gramsci; emancipation; subaltern classes. 


\section{GRAMSCI ET L'EMANCIPATION DU SUBALTERNE}

\section{Marcos Del Roio}

Dans les Cahiers de Prison, Gramsci s'est servi de la notion de classes et de groupes subalternes, concept employé désormais par les Sciences Sociales et par l'Historiographie actuelle. De même, les problèmes du sens commun, du folklore et de la religion y figurent. Il est important de mettre en question les implications théoriques et politiques de la pensée de Gramsci, et ainsi la constextualiser dans l'ensemble de sa production théorico-politique, pour refuser l'usage courant de ce concept et sa vraie relation avec Gramsci. Il faut aussi examiner à quel point cet auteur doit être considéré comme actuel pour l'interprétation des conditions des luttes sociales dans le capitalisme contemporain. MOTS-CLÉS: Antonio Gramsci; émancipation; classes subalternes. 